\title{
The Development of Innovation Infrastructure in Crimea Region
}

\section{Nalivaychenko Ekaterina}

\author{
Doctor of Economics, Professor, Professor of the Department of Business Economics, V.I. Vernadsky Crimean Federal University \\ Russia, Simferopol, Sevastopolskaya st., 21/4, 295015; E-mail: ekaterina@online.ua
}

\begin{abstract}
Kirilchuk Svetlana
Doctor of Economics, Professor, Chief of the Department of Business Economics, V.I. Vernadsky Crimean Federal University Russia, Simferopol, Sevastopolskaya st., 21/4, 295015; Corresponding author's mail: skir12@yandex.ru
\end{abstract}

\section{Doi:10.5901/mjss.2015.v6n6s2p396}

\begin{abstract}
This article deals with major problems of sensibility of business' economy to innovations and their solution within social and economic growth of Crimea. The article presents problems of implementation of innovation infrastructure policy in Crimea. Market dissolution of cross-sectoral barriers does not provide secure horizontal interdependencies, so a reasonable strategic decision mechanism in the sphere of innovations needs to be organised and developed. In this article we demonstrate the need for transformation of internal and international profile of Crimea: progressive development of high-technology products and services. In addition, we evaluate prospects for state commercialisation of scientific results.A solution to a problem of Crimea innovation infrastructure development can provide steady social and economic development of Russian economy within innovations. Implementation of innovation regional infrastructure policy would present local enterprises with landmarks for development of long-term projects, exploration of new local and foreign market niches withing the "knowledge-based economy". At that, there are several more important components of regional strategy for development of innovation infrastructure: progressive trasformation of type of international specialization, export diversification, expansion of market share of home high-technology products and services.
\end{abstract}

Keywords: innovations, regional economy, development strategy, innovation infrastructure, innovation development models, knowledge-based economy, high-technology products, competitive capability, commercialisation of technologies.

\section{Introduction}

At current stage of transformation of Russian economy following tasks remain quite relevant: development of innovation infrastructure of national economy and regional economy, implementation of technological advances. These problems need to be solved as soon as possible for competitive growth of home business' economy based on innovations.

\section{Methods}

Conceptual framework of realisation of innovation development models within capitalistic economic system was studied by scientists of different schools of thought: J. Schumpeter, S. Kuznets, G. Mensch, M. Kondratiev, A. Klainknecht, J. van Dyne, K. Friedman, J. Clark, Yu. Yakovets, M. Porter, O. Y. Volynets-Russet, N. V. Apatova, V. V. Trofimova, N. I. Ivanova, N. I. Komkov.

Within an innovation model, the innovation is regarded as a main drive for economic development, that is a cause of repeating pattern and can be activated at different stages of economic development - at a stage of growth as well as at a stage of regress.

\section{Results}

Innovation model of economic development is a broad economic category, so it is quite difficult to clearly identify its paradigm features. We should mention contribution of $\mathrm{M}$. Porter into the theory of innovations within international economy. He identified 3 levels of innovation models: top tier countries, converging top tier innovators and emerging innovators (Table 1) [Porter, 2001]. 
Table 1. Levels of Industrial Models of Innovative Development

\begin{tabular}{|l|l|l|l|}
\hline Model & America & Europe & Asian-Pacific Region \\
\hline Top Tier Countries & The USA & Switzerland, Sweden, Germany, Finland, Denmark & Japan \\
\hline Converging Top Tier Innovators & Canada & $\begin{array}{l}\text { France, Italy, Austria, Norway, the United Kingdom, } \\
\text { Spain, the Netherlands }\end{array}$ & Australia, New Zealand \\
\hline Emerging Innovators & Ireland, Israel & Singapore, Taiwan, South Korea \\
\hline
\end{tabular}

A model of top tier countries is a pioneer innovation model. It was realised in XX century in the USA, and is still partly used in Japan, Switzerland, Sweden, Germany, Finland and Denmark.

Realisation of models of converging top tier innovators allows holding large market shares in certain spheres.

Among emerging innovators models we may name an innovative partnership model of Israel, which provides realisation of strategic partnership with the USA on the base of proper independent research centre; an interventional model of innovative development of Ireland, that provides conditions for development upon foreign investments; an Asian innovative development model, aimed at adaptation of foreign experience for development of proper research base and production infrastructure.

The USA's strategy of partnership with a certain country will depend on the type of model used within that country, and on strategic course being implemented [Volynets-Russet, 2008]. As to the partnership between the USA and European countries, we may characterise it as synergetic (possibility of preservation of existing scientific research departments in transnational corporations, prognosis for retention of current disposition of competitive forces). Pacific vector can be defined as potentially conflictogenic: in the long view there is a possibility of international economic conflicts between the USA and countries of the Pacific Rim, breach of existing research alliances, overall increase of competition.

Within a capitalistic system, innovative economic model should have following features: capability to promote competitive economic development by means of innovations of different levels and types, as well as to promote adequate adaptation of other components of a model. National economic model can be defined as a complex theoretical and methodological system that is realised (may be realised) within given regularities at a certain level of the State's economic development and can promote adequate level of human wellbeing, safe independent competitive balanced development on the basis of realisation of economic policy in accordance with endogenous and globalisational factors of development. But at this it should be borne in mind that realisation of a new innovation model in a certain country particularly depends on historical background, social and cultural peculiarities, which in their turn, define configuration of components of a national economic model. Realisation of this model during the XX century allowed certain countries to go through quick industrialisation, increase human wellbeing, reach global leadership as to certain marks of economic development [Apatova, 2011; Trofimova, 2009; Ivanova, 2005; Komkov, 2005].

In XXI century efficacy of innovative models in leading countries will be threatened by following:

- increase of aggregate innovative capacity of countries;

- transformations at the market of knowledge and innovation, caused by the concept of open innovation that leads to a need for facilitation and reformation of global system of protection of intellectual property;

- spread of economic processes behind national boundaries - components of national models acquire global features and, appropriately, the states need to acquire global functions;

- outbreak of new economic system formation - the global knowledge-based economy, within which an issue of global leadership loses its importance to independent competitive economic development;

- transformation of countries' competitive advantages according to their participation in global circulation of productive forces; human factor becomes the key one;

- absence of efficient and just institutions of global management.

We hold a scientific theory that a stage of development should be named after the prevailing resource (capital is prevailing - capitalism, knowledge is prevailing - knowledge-based economy). Definition of knowledge-based economy as post-industrial is conditioned by increase of certain parts of service industry in GDP, increase of part of population employed in this sphere, increase in knowledge content of products, increase in time consumed by a person for data processing and knowledge generation depending on level of public responsibility and level of mastery in modern knowledge. Development of knowledge-based economy is possible only under quite high level of development of constitutional state and civil society [Lysenko, 2011].

Countries, which in XX century realised innovation models of development, enter the global knowledge-based economy with different strength reserve. Thus, export-oriented, industrialised and interventional models provided grandscale mastering of capital-intensive spheres bypassing the stage of labour-intensive manufacture, which allowed to save 
human resource (as is shown by experience of Ireland). Asian countries, to the contrary, went through the "whole circle" from specialisation on labour-intensive manufacture to capital-intensive one via a coherent transition. The epoch of lowcost labour is gradually terminating as establishment of global knowledge-based economy provides more fair distribution of incomes worldwide, conditioned by new competition between countries for human resource as the most important one.

XXI century would be marked by establishment of global knowledge-based economy, evidence of which is already observed in the sphere of manufacture, distribution, change and consumption. Noospheric type of consumerism has already become a major type of consumption. Due to transnationalism, manufacturing assumed global scale. Currently the spheres of distribution and change are being globalised. As to the sphere of change, it should be noted that the effect of the law of supply and demand and the principles of price policy are going through universal transformations. Deployment of global inflation processes activate search of possibilities for creation of single world currency and supersession of national currencies of auxiliary type. As to the sphere of distribution, we would mention that earlier it concerned mostly avoidance of dual taxation, regulation of investment flow between countries etc., but at present there are many new problems which do not have any solution. In particular, there is no even theoretical efficient funding mechanisms for creation of global common weal, solution of current global problems (for example, the ones conditioned by climate change), establishment of system for global monitoring of economic and ecological development, system for estimation of global risks etc., so innovative models should be focused on solution of these tasks [Todosiychuk, 2010].

Taking into account paradigm features of emerging economic system of knowledge, we may consider following factors to be peculiarities of innovation development models within the establishment of the global knowledge-based economy:

- prevalence of innovations in the sphere of services;

- attention to innovations of global level;

- possibility for creation of pioneering technological innovations solely at international level, which determines establishment of new international research groups;

- states take up global functions in order to optimise their participation in global circulation of productive forces;

- reformation of registration system and defence of intellectual property rights;

- reformation of existing international financial system, establishment of global financial institutions of redistribution of world income under new principles;

- stable development, openness and flexible character of components of national models are going to be key principles of global economic development.

Infrastructure of national economy includes a sphere of applied research, practical studies and exploitation of innovations, which are funded in Russia from the national budget as well as by business sector. Innovations are being commercialised - by this we mean a process of budgeting of innovations and staged control of expenditures, including evaluation and transfer of complete and commercially utilised results of innovative activity. Commercialisation processed within modern market integrate functions of budgeting, innovation management and transfer of results in order to focus them at positive commercial (i.e. self-sustaining) result. Among funding sources of innovative technologies in Russia majority is represented by equity capital of companies $-70.0 \%$ of total (though, in absolute terms it amounts to only 169.9 billion RUR in 2013), other capital $-24.3 \%$, the rest is represented by: the national budget, budget of territorial entities of the RF and local budgets, non-budgetary funds: $4.4 \%, 0.1 \%$ and $0.07 \%$ respectively. Part of foreign investors equals to $1.1 \%$, which is a very low-profile figure (Picture 1) [Federal State Statistics Service, 2014].

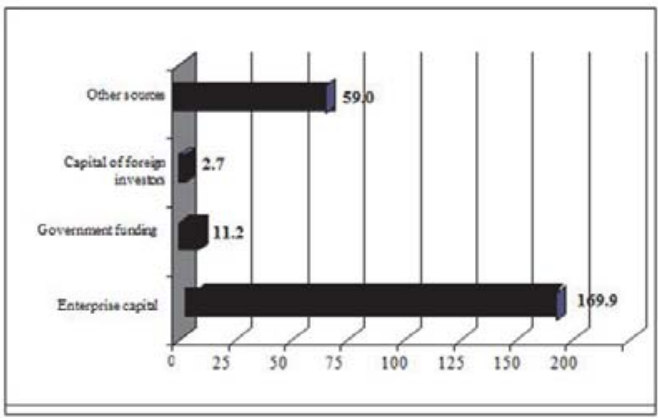

Picture 1. Volume of costs according to sources of fundation of innovation technologies in Russia in 2013, billion of RUR. 
Expenditures for research and development by types of studies (fundamental, applied, sci-tech service etc.) has little changed over last years, and has mostly been funded by the government and corporate sector under the secondary principle.

Indicated problems stipulate the need for organisation of effective mechanisms of their solution, taking into account peculiarities of Russian science sector integration into international society. However, the position of business sector in innovation sphere of national economy still has some perspectives. Some of the companies are focused not only at retention of their status-quo, but also at constant renewal. At the same time, entrepreneurs often utilise technological innovation at a minimum, as elementary organisational and marketing innovation are more effective [Odotuk, 2007]. Majority of formal criteria for estimation of company's innovativeness produce distorted perspective [Umanets, 2010]. Thus, an indicator of proportion of R\&D in the total scope show a significant variation from several dozens of percent (which excel the best figures of foreign companies) to nearly zero. In majority of companies this parameter does not run at even one tenth of a percentage point. The same situation is observed as to criteria of innovativeness (patents, sales of licences revenue, part of innovative products in total volume of sales etc.). To conduct a study, we shall group companies with similar models of innovative activity: for example, according to processing complexity of manufacture. For this purpose we can use method of OECD with 4 groups of economic branches (Picture 2).

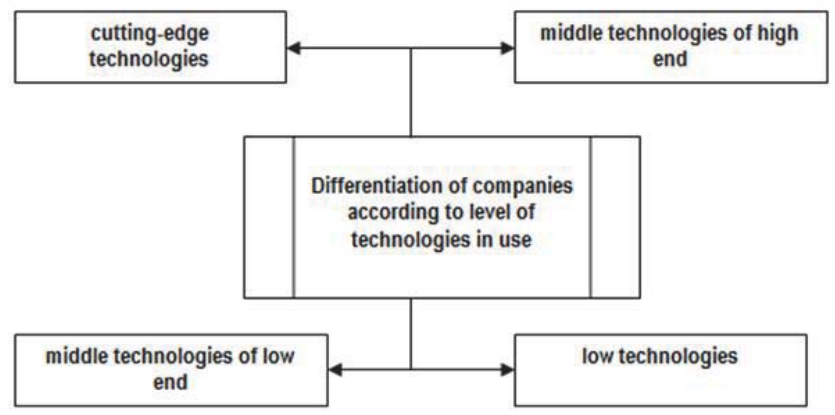

Picture 2. Differentiation of Companies According to Level of Technologies in Use by OECD Method

However, it is clear that just belonging of a company to this or that technological group does not define its innovativeness. It is necessary to take into account the factor of company's performance, management and staff, operational efficiency of research departments. All these factors within market economy are conditioned by tensity of competitive situation surrounding the company. Share of exports in company's income can serve as the second indicator. It is crucial that both the first and the second indicators are objective and easy to define on the basis of statistic data.

We suggest that differences in innovative activity of companies are usually connected with following aspects:

a) priorities of innovative activity: focus at development of new products, improvement of existing products, changes in sales system and business process management;

b) innovation infrastructure: proper R\&D centre and branched organisation of research sector;

c) decision-making hierarchy: stage of involvement of top-managers into development and implementation of innovation policy;

d) innovation network: stable links to external source of innovations (research institutes, universities, innovative companies, foreign centres).

Nearly half of local companies of processing industry do not experience intense competition from foreign companies as they mosly work at relatively small segments of domestic market, sticking to the limits of their region. That is the reason why companies do not have motivation for constant modernisation of manufactured products and capital stock, preventing them from innovative development [Interdepartmental Analytic Centre, 2014]. To a certain extent, allocation of funds for R\&D from all the sources (state and private) is impeded by significant risk present upon execution of an innovation project. In well-developed countries innovation process presents not less of risk. However, in such countries there is an infrastructure and mechanisms for financial flows management, supported by the State and the market - they mitigate risks to acceptable level and "filter" over-risky projects and ideas, withholding them from early implementation. This management technique assigns important role to the market of intangible assets, innovation agents 
etc. (Table 2) [Russian Research Institute of Economics, Politics and Law in Science and Technology, 2014].

\section{Discussion}

Innovation breakthrough of Crimea demands determining of strategic scientific and technological priorities, national competitive advantages, establishment of innovative infrastructure, certain inventory of intellectual resources and a new level of interrelations between the State and business. Modern stage of development is characterised by high degree internationalising of innovation sphere, when a single country cannot achieve a massive innovation breackthrough on its own. Here stands a task to take rightful place in the process of international differentiation of labour in a knowledgeconsumptive sphere. Principles of organisation and architecture of world innovation sphere are under significant changes. For example, efficiency of traditional technology parks, located at a definite territory, is declining.

Science systems integrator (SSI) becomes a more adequate form of organisation of innovation activity as it allows to apply elements of research and industrial infrastructure, that are most reasonable for project execution. Certainly, a key factor of SSI is a human factor. Project developers study the market, shape goals and tasks, find performers and suppliers from different countries, control final stages of implementation of new technology and provide its commecialisation.

At present import of crude materials, food and consumer goods prevail [Ministry of Economic Development of the Russian Federation, 2014]. Under this situation it would be difficult to provide massive renovation of major production assets, creation of new high-tech companies, implementation of management know-hows. In addition, composition of procurement of investment equipment and technologies can be changed. At present Crimean companies generally purchace miscellaneous or complex equipment (machinery, processing centers, production trains etc.). This promotes fast start-up of new products, but not always allows for innovative development of domestic industry. In this context increase in purchses of licences and know-hows seems to be more resonable, as it allows to create collaborative hightech projects together with the licenser, with a possibility to later make a transition to proper innovations. Global practice shows that volume of expenditures for foreign licenses does not exceed $30-40 \%$ of investment into proper R\&D. Additionally, more than $50 \%$ of engineering products manufactured in the worls are produced under licence [Pavluk, 2011]. Thus, a thoughtful choise and effective development of priority areas of technological advances are a crucial task for the State and private sector. Funding level of research work is considered to be major productive power; in 2013 it achieved following numbers: Israel $-4.3 \%$, the USA $-2.6 \%$, France, Japan $-3 \%$, Russia $-0.6 \%$, Ukraine $-0.1 \%$ of GDP [Kuznetsova, 2014].

Table 2. Experience of funding of technology commercialising in well-developed countries

\begin{tabular}{|c|c|c|}
\hline Funding & Decision-making mechanism & Country \\
\hline $\begin{array}{l}\text { Development of mechanism of } \\
\text { state financing backing of R\&D }\end{array}$ & $\begin{array}{l}\text { Government lending and borrowing (reimbursable) and grants; state } \\
\text { guarantees for bank loans; government order for R\&D of strategically } \\
\text { important products; interest in scientific research (up to 50\%); tax incentives; } \\
\text { accelerated capital allowance; export and import quotas for support of } \\
\text { national knowledge-consumptive product; tax deferment upon investment in } \\
\text { proper R\&D; state funding of expenditures for patents and patent vindication } \\
\text { (about 10\%) }\end{array}$ & $\begin{array}{l}\text { The USA, Italy, } \\
\text { Belgium, the UK, } \\
\text { Sweden, Canada }\end{array}$ \\
\hline \multirow[t]{4}{*}{$\begin{array}{l}\text { Support of national providers } \\
\text { of innovations }\end{array}$} & $\begin{array}{l}\text { Implementation of modern mechanisms for reduction of R\&D material } \\
\text { expenses (advancing of client at a stage of scientific inquiry, protection of } \\
\text { future market, engaging of foreign scientists from knowledge community of } \\
\text { created product, early protection of brand names) }\end{array}$ & $\begin{array}{l}\text { EU, the USA, } \\
\text { Japan }\end{array}$ \\
\hline & Support of program for development of national brands & $\begin{array}{l}\text { The USA, Japan, } \\
\text { EU, South Korea }\end{array}$ \\
\hline & $\begin{array}{l}\text { Support of small and mid-sized innovative business through antitrust } \\
\text { enforcement against major companies - owners of intellectual property. }\end{array}$ & EU, the USA \\
\hline & $\begin{array}{l}\text { Co-funding of companies' initiatives through a licensing system or } \\
\text { establishment of spin-off companies (government department from its fund } \\
\text { supports about } 20 \text { patenting and patent-using agencies, rating and } \\
\text { innovation commercialising agencies for several local universities, as well as } \\
\text { for non-university research institutions) }\end{array}$ & Germany, the UK \\
\hline $\begin{array}{l}\text { Selection of highly profitable } \\
\text { results for commercialisation }\end{array}$ & $\begin{array}{l}\text { Development of innovation agent mechanism between state R\&D, academic } \\
\text { research and private business - by organisations for transfer of technologies }\end{array}$ & EU, the USA \\
\hline
\end{tabular}


Lately a trend for decrease of part of innovative companies in the total of industrial enterprises was observed in Crimea (Table 3). Thus, in the period from 2000 till 2010 this number statistically reduced from $12.1 \%$ to $9.9 \%$. In addition, the quantity of new types of products decreased, as well as number of companies which bought and implemented new types of mechanisation and manufacturing automation for execution of innovations (Table 4). During the same period volume of sales of innovation products and export volume also decreased (Table 5) [Innovative activity of Industrial Enterprises: Statistic Data, 2014]. Taking into account the abovementioned, let us consider priority areas of R\&D (research and development) and corresponding innovative projects in Crimea industrial complex (Picture 3, Table 6).

Table 3. Number of Crimean Companies Which Implemented Innovations

\begin{tabular}{|l|c|c|c|c|c|c|}
\hline & \multicolumn{5}{|c|}{ Total } \\
\cline { 2 - 8 } & 2000 & 2005 & 2007 & 2008 & 2009 & 2010 \\
\hline Total & 33 & 19 & $\mathbf{2 5}$ & $\mathbf{3 0}$ & $\mathbf{2 3}$ & $\mathbf{2 3}$ \\
\hline utilised new technological processes & 13 & 10 & 10 & 12 & 14 & 12 \\
\hline including the low-waste, resource-saving and non-waste ones & 7 & 4 & 7 & 8 & 9 & 7 \\
\hline grasped manufacture of new types of products & 32 & 12 & 14 & 21 & 16 & 16 \\
\hline including new types of machinery & 7 & 3 & 4 & 6 & 7 & 7 \\
\hline implemented complex mechanisation and automation of manufacturing & 2 & 6 & 18 & 24 & 23 & 27 \\
\hline Sold innovative products & 23 & 24 & 23 & 28 & 20 & 18 \\
\hline
\end{tabular}

Table 4. Implementation of Progressive Technical Process and Grasping of New Types of Products in Crimean Industry

\begin{tabular}{|l|c|c|c|c|c|c|c|}
\hline & 1995 & 2000 & 2005 & 2007 & 2008 & 2009 & 2010 \\
\hline Total & 154 & $\mathbf{5 7 2}$ & $\mathbf{1 2 5}$ & $\mathbf{7 9}$ & $\mathbf{1 2 1}$ & $\mathbf{9 3}$ & $\mathbf{9 5}$ \\
\hline Implemented new progressive technical processes & 41 & 68 & 62 & 24 & 73 & 47 & 32 \\
\hline including the low-waste, resource-saving and non-waste ones & 17 & 7 & 22 & 16 & 36 & 25 & 15 \\
\hline Grasped manufacture of new types of products, items & 113 & 504 & 63 & 55 & 48 & 46 & 63 \\
\hline including new types of machinery & 11 & 18 & 38 & 26 & 27 & 15 & 26 \\
\hline
\end{tabular}

Thus, under modern "knowledge-based economy" key factor of development of Crimea economy is activation of innovation process. Major priorities of innovative development of the region are following:

- implementation of energy-efficient and resource-saving technologies, renewable power sources;

- development of resort and health sphere;

- implementation of new technologies in the sphere of farming industry, development of biotechnology;

- local development of innovative infrastructure and innovative culture of society;

- development and modernisation of transport infrastructure.

Table 5. Volume of Innovative Products Sold in Crimea

\begin{tabular}{|c|c|c|c|c|c|c|}
\hline & 2000 & 2005 & 2007 & 2008 & 2009 & 2010 \\
\hline Total & 78,7 & 932,2 & 624,0 & 280,1 & 174,5 & 163,0 \\
\hline including fundamentally new ones* & 12,8 & 883,9 & 92,1 & 111,5 & 76,8 & 26,1 \\
\hline Exported out of total & 50,2 & 353,3 & 232,1 & 102,4 & 38,4 & 49,9 \\
\hline
\end{tabular}

* Since 2007 - products new to the market. 


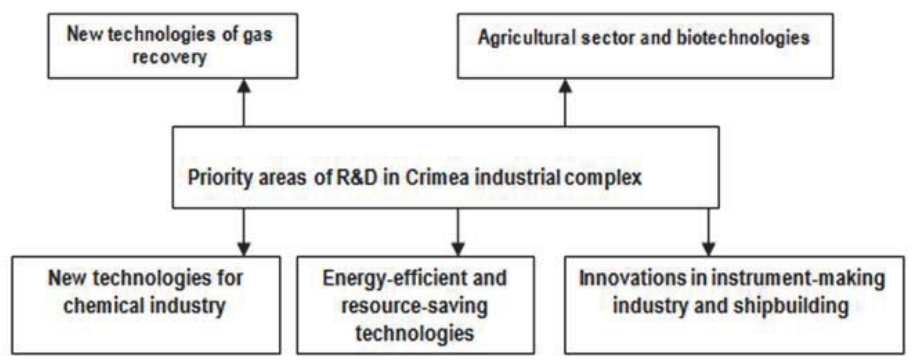

Picture 3. Priority Areas of R\&D in Economy of Crimea

Some of the most innovatively active companies of the peninsula are:

- food industry enterprises: PAO Krymmoloko, PAO Beer Non-alcoholic Combine "Krym";

- chemical industry enterprises: ZAO Krymski Titan, PAO Simferepolski Zavod Plastmass;

- machine industry enterprises: PAO Firma SELMA, OOO Kerchenski Strelochni Zavod, PAO Simferepolski Motorni Zavod, PAO Zavod Fiolent, PAO Pnevmatika [Innovative activity of Industrial Enterprises: Statistic Data, 2014].

The system of regional innovation management should certainly take into account peculiarities of different areas in a given region and current situation in institutional transformation of management organisation, structure of property assets, as well as position at the market of goods and services.

Real transition to realisation of innovation strategy is a precondition of successful social and economic development of Crimea. This strategy would allow companies to state marks for development of long-term projects for grasping of new niches at local and international market.

Table 6. Innovative Projects in Crimea

\begin{tabular}{|c|c|}
\hline PROJECT INITIATOR & ORDER NUMBER AND NAME OF AN INNOVATIVE PROJECT \\
\hline $\begin{array}{l}\text { Alushta Manufacturing Facility of Water and } \\
\text { Sewage Services Company }\end{array}$ & 1. Compensation of reactive power consumed by automatic equipment \\
\hline OAO BROM & $\begin{array}{l}\text { 2. Establishment of complex for production of chlorine and caustic soda - } \\
\text { establishment of new process unit of the chemical industry }\end{array}$ \\
\hline Feodosia State-Owned Plant & $\begin{array}{l}\text { 3. Development and organisation of mass production of innovative products on the } \\
\text { basis of laser and quantum technologies }\end{array}$ \\
\hline $\begin{array}{l}\text { KRP Manufacturing Facility of Water and Sewage } \\
\text { Services Company }\end{array}$ & 4. Automatic frequency-controlled control system for electric pump \\
\hline OAO Primorets & 5. Motor pleasure yachts of FMY2300S 2 tly project \\
\hline OAO Zolotoe Pole & 6, 7. Complex innovative project Grape Growing with the Use of New Technologies \\
\hline $\begin{array}{l}\text { South Biotechnical Centre of Crop Farming } \\
\text { Horticultural Institute } \\
\text { Crimea Institute of Agribusiness }\end{array}$ & $\begin{array}{l}\text { 8, 9. Development and implementation of a technology for obtaining and reproducing } \\
\text { of virus- and pathogen-sanitized super elite planting material of release promising } \\
\text { varieties of fruit and ornamental culture, and grape }\end{array}$ \\
\hline OOO Nova-Eco & 10. Wind power plant building \\
\hline OAO Sovkhoz Vesna & 11. Cultivation of new fruit varieties \\
\hline Farming Enterprise Demetra & 12. Implementation of new technologies for grain growing \\
\hline $\begin{array}{l}\text { Crimea Vegetable Research Station of Institute of } \\
\text { South Vegetable Research and Melon Cultivation }\end{array}$ & $\begin{array}{l}\text { 13. Scientific support of effective agriculture and selection of vegetable and melon- } \\
\text { field southern cultures, production of seeds of elite vegetable and melon-field cultures }\end{array}$ \\
\hline $\begin{array}{l}\text { South Experimental Station of Agricultural } \\
\text { Microbiology Institute }\end{array}$ & 14. Work upon development of new biological products \\
\hline \multirow[t]{4}{*}{$\begin{array}{l}\text { South Branch of Crimea University of Agricultural } \\
\text { Technologies }\end{array}$} & $\begin{array}{l}\text { 15, 16, 17. Adaptive technologies for cultivation of strong winter wheat and perennial } \\
\text { legume grasses and chick-pea in Crimea }\end{array}$ \\
\hline & 18. Environmentally safe cost-effective technology of rice cultivation \\
\hline & 19. Development of scientifically grounded system of fertilizer application \\
\hline & 20. Aerosol therapy of respiratory disease in calves \\
\hline
\end{tabular}

Gradual reformation of type of Crimean international specialization, exports deversification and exapansion of market 
share of domestic high-tech products and services are among the most crucial aims. Term of commencialisation of scientific results define objective need for development of innovation infrastructure and following in-depth study of this problem and search of effective solution mechanisms.

However, despite increase of relative share of innovative products sold in the total of industrial products since 2011, some measure of innovative activity in Crimea industrial enterprises tend to decrease in recent years (Table 7).

Table 7. Implementation of Innovations at Industrial Enterprises of Crimea

\begin{tabular}{|c|c|c|c|c|c|c|}
\hline Year & $\begin{array}{c}\text { Relative share of } \\
\text { enterprises, implementing } \\
\text { innovations, \% }\end{array}$ & $\begin{array}{c}\text { New technological } \\
\text { processes } \\
\text { implemented }\end{array}$ & $\begin{array}{c}\text { including the low- } \\
\text { waste and resource- } \\
\text { saving ones }\end{array}$ & $\begin{array}{c}\text { Innovative } \\
\text { products } \\
\text { grasped, items }\end{array}$ & $\begin{array}{c}\text { including new } \\
\text { types of } \\
\text { machinery }\end{array}$ & $\begin{array}{c}\text { Relative share of } \\
\text { innovative products sold } \\
\text { in the total of industrial } \\
\text { products, } \%\end{array}$ \\
\hline 2004 & 13,3 & 90 & 21 & 356 & 8 & 12,3 \\
\hline 2005 & 6,6 & 62 & 22 & 63 & 38 & 14,5 \\
\hline 2006 & 6,1 & 11 & 7 & 54 & 30 & 7,9 \\
\hline 2007 & 8,7 & 24 & 16 & 55 & 26 & 6,5 \\
\hline 2008 & 9,9 & 73 & 36 & 48 & 27 & 2,3 \\
\hline 2009 & 6,8 & 47 & 25 & 46 & 15 & 1,4 \\
\hline 2010 & 6,9 & 32 & 15 & 63 & 26 & 1,1 \\
\hline 2011 & 11,2 & 66 & 38 & 73 & 49 & \\
\hline 2012 & 9,9 & 43 & 18 & 53 & 38 & 1,7 \\
\hline 2013 & 8,2 & 35 & 17 & 100 & 17 & 2,3 \\
\hline
\end{tabular}

At the same time, relative share of companies, implementing technological, organisational or marketing innovations in the total of studied companies in Russia amounted to: in 2009 - 9.3\%; in $2010-9.5 \%$; in $2011-10.4 \%$; in $2012-10.3 \%$; in $2013-10.1 \%$ [9].

Following reasons can be regarded as major reasons for decrease of innovative activity of Crimea market participants:

- inadequacy of legal acts, regulating transition of region's economy to investment-innovative way of development;

- lack of coordination of work of infrastructure organisations in innovative sphere;

- $\quad$ no adequate financial support of innovative activity in the region;

- weak interaction of entrepreneurship and science;

- insufficient human resourcing of innovative activity [Innovative Investment in Crimea, 2008].

One of the most important mechanisms for promotion of innovative activity is a financial support of companies. At present there are following types of state support in Crimea: support of innovative (investment) projects, support of "small business" enterprises, economic incentive for companies-manufacturers of excisable goods (Picture 4) [Types of Financial Support in the Autonomous Republic of Crimea, 2014].

In order to solve major problems of innovative activity in Crimea, there should be a regional innovation infrastructure with following priority tasks:

- development of network of new innovation infrastructure elements, namely regional innovation clusters, innovation business incubators etc.;

- support and development of small innovative enterprises;

- informational support and consulting in the sphere of innovations;

- staff training for the sphere of innovative activity.

Thus, the Innovation Committee of the Crimea Chamber of Commerce and Industry approved the Concept for Establishment of Regional Technical Platform "Sustainable Development of Crimea" [Chamber of Commerce and Industry of Crimea, 2014]. Main aim of the technological platform is to create modern "green" economy and mechanisms of sustainable development on the basis of resource-saving and energy-efficient, low-waste technologies, as well as active use of renewable power sources.

With regard to the above mentioned, it is planned to use following mechanisms for practical support of manufacturing facilities and entrepreneurs:

- execution of difficult works and costly measures associated with development, installation and putting in operation of specific equipment by specialist contractors and organisations-participant of technological 
platform;

- establishment of a utility unit (as a part of Crimea Chamber of Commerce), that performs specific functions on a contractual basis: energy and ecological audit with involvement of certified auditor, elaboration of measures for improvement of energy efficiency and ecological safety, assistance to entrepreneurs in the realisation of organisational and other events.

Thus, solution of current problems of innovative activity demands further development of mechanisms of financial incentive, development of regional innovation infrastructure, pooling of intellectual and financial resources for efficient realisation of innovation and investment programs and projects in the territory of the Republic of Crimea.

A notion of competitive ability of the region is inextricably connected with the notion of its economic activity (by latter is meant a grounded process of regional economic and social system functioning, aimed at effective use of resources of this territory for achievement of market competitive ability of market participants and increase of human wellbeing). In order to define region's economic activity it is usual to use generalised performance characteristic of economy of the region, which includes efficiency of resources use in all the spheres of business, management quality and possibility of economic growth, financial security and wellbeing of people. In addition, it is recommended to use investment and innovation activity, as well as social, economic, financial activity and level of environmental safety in the region. The result allow to asses functioning of different sub-systems of regional complex within economic activity and to draw conclusion at to the nature of active processes in the region.

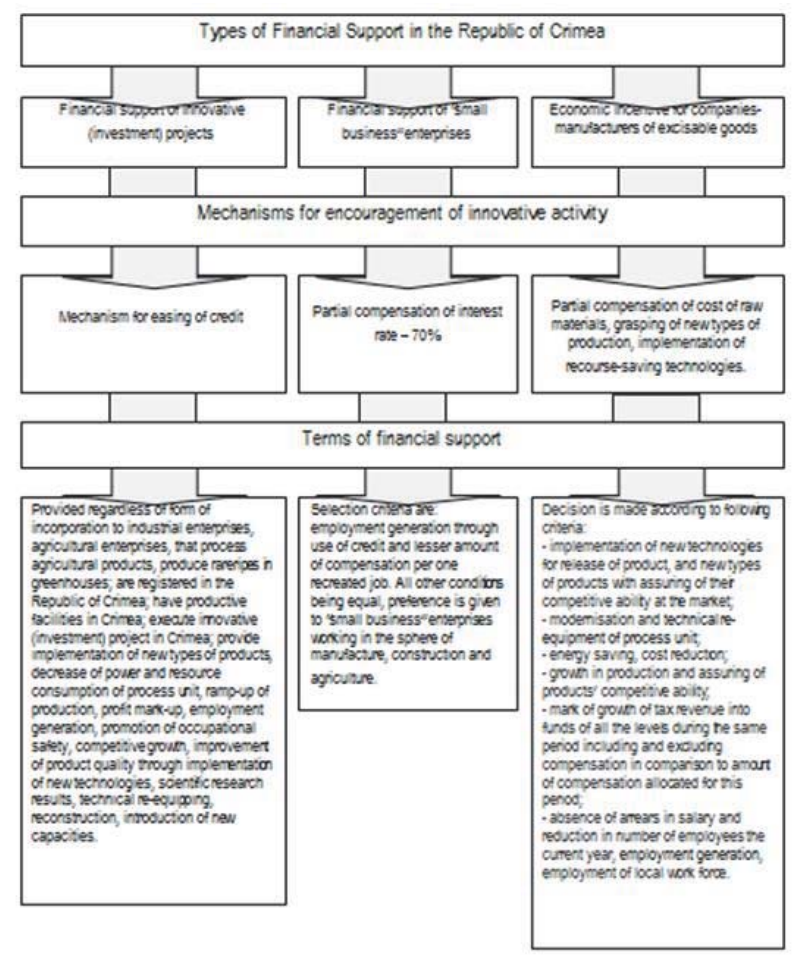

Picture 4. Types of Financial Support in the Republic of Crimea

\section{Conclusion}

These conclusions are the basis for adjustment of strategic goals and management decision making as to laying down of regional development programs. They give an opportunity to get overall estimate of economic activity in Russia and its dynamics. According to Russian economist V.S. Yakushin, the strategy of innovative development should comprise the market as the basis for realisation of innovative development, creation of sci-tech product and a stage of its commercial 
exploitation [Yakushin, 2006].

In order to make a transition over to innovation model of development, Crimea needs to establish the market of innovations, promote communication between subjects of sphere of innovation creation and the companies, develop and realise new innovative programs, induce industrial and agricultural enterprises to innovative activity. Many of Crimea companies have almost no systems for knowledge management and appraisal of possible new releases, no proper bank of ideas and technologies.

Regional innovation system can be established under total penetration of innovations into all the spheres of social activity. At this, the culture of innovation implementation is very important - the need of every person for development and implementation of innovations as driving force of prosperity [Nalivaychenko, 2013].

Regional economic model can be defined as a complex theoretical and methodological system, that is realised within given regularities at a certain level of the State's economic development and can promote adequate level of human wellbeing, safe independent competitive balanced development on the basis of realisation of economic policy in accordance with endogenous and globalisation factors of development. But at this it should be borne in mind that realisation of a new innovation model in a certain region particularly depends on historical background, social and cultural peculiarities, which in their turn, define configuration of components of the model.

Further research of the authors is aimed at scientific support of concept of innovation culture development within economic activity, which is regarded as a major factor strengthening the synergism of interaction between components of the national economic model.

\section{References}

Apatova N.V. Target-oriented Approach to the Creation of Development Strategy. Proceedings of Taurida National V.I. Vernadsky University. Series: "Economics and management". 2011. Vol. 24 (63). No. 1. P. 3-9.

Chamber of Commerce and Industry of Crimea. URL: http://cci.crimea.ua

Innovative activity of Industrial Enterprises: Statistic Data. Local Agency of the Federal State Statistics Service in the Republic of Crimea (Krymstat). URL: http://gosstat.crimea.ru/ukgnauinv4.php\#_inov

Innovative Investment in Crimea. Data of the Department of Economic Affairs of the Autonomous Republic of Crimea. Materials from the research and training conference "Science and Business. Problems of Development of Small Innovative Ventures". Simferopol: Mineconom ARK, 2008. P. 4-7.

Interdepartmental Analytic Centre. URL: http://www.iacenter.ru

Ivanova N.I. National Innovation Systems. Moscow: Nauka, 2005. 385 p.

Kirilchuk S.P., Nalivaychenko E.V. Transformation of Innovative-Investment Processes in the Economic Activity: Monograph. Simferopol: ARIAL, 2013. $330 \mathrm{p}$.

Komkov N.I. Predictive Modelling and Economic Justification of Innovative Processes: Monograph. - Moscow: INP RAN, 2005. 235 p.

Kuznetsova G.V. Development of Research Activity in the World Economy. Rossiyskiy vnechneeconomichenskiy Vestnik, No. 72014. URL: http://www.rfej.ru/rvv/id/2003EDBCD/\$file/23-40.pdf

Lysenko Yu.G. Reflexive Processes in Economics: Concepts, Models, Applied Aspect: Monograph. - Donetsk: Yugo-Vostok, 2011. 422 p.

Ministry of Economic Development of the Russian Federation. URL: http://www.economy.gov.ru

Nalivaychenko E. Directions to Achieve Synergy Effects of Innovations in the Information Business. Nauka i Studia. No. 37(105). Przemysl: Poland, 2013. P.66-71.

Odotuk I.V. Innovative Transformation of Russian and Ukrainian Industry. Problems of Forecasting. 2007. No. 6. P. 15.

Pavluk S.M. Development Institutions as an Instrument of State Support and Promotion of Investment Activity. Nauka $j$ economika (Theoretical science journal of Khmelnytskyi Economic University). No. 3(23). 2011. P. 116-122.

Porter M.E., D. van Opstal. U.S. Competitiveness 2001: Strengths, Vulnerabilities and Long Term Priorities. Council on competitiveness: Washington, 2001. $86 \mathrm{p}$.

Russian Research Institute of Economics, Politics and Law in Science and Technology. URL: http://riep.ru

Science and Innovations. Federal State Statistics Service. URL: http://www.gks.ru./wps/wcm/connect/rosstat_main/rosstat/ru/statistics/ science_and_innovations

Todosiychuk A. Conditions of Transition to Innovation Economy. Economics. 2010. No. 2. P. 25-38.

Trofimova V.V. Regional Innovation Complexes in Global Economy: Monograph. Simferopol: ViTroPrint, 2009. 260 p.

Types of Financial Support in the Autonomous Republic of Crimea: Promotion of Investment Activity. Innovation Portal of the Republic of Crimea. URL: http://www.innovations-crimea.gov.ua/content.php?cid=vfp\&mid=156

Umanets T.V., Luchakova O.V. Indicator System for Assessment of Innovation Development. Reporter "Problemy economiky ta upravlinnya". No. 684. Lviv: Lviv Polytechnic, 2010. P. 260-268.

Volynets-Russet J.J. Know-How in Foreign and Internal Trade. Moscow: Rota-print VAVT, 2008. 325 p.

Yakushin V.S. Strategy of State Support of Russian Innovation Complex in the Present Context of Global Industrial Relations: Doctor of Economics Thesis. Moscow, 2006. 283 p. 